\title{
NOAA at sea: who will be named to take over the helm?
}

\section{Washington}

HAving lost its administrator and with no replacement yet named, it is again being asked on Capitol Hill whether the National Oceanic and Atmospheric Administration (NOAA) can function effectively as part of the Department of Commerce.

Although it receives about half the department's budget, its research and weather forecasting functions have always seemed out of place in an agency that is also responsible for economic development and trade policy. But despite interest from Congress, NOAA is unlikely to be moved out of Commerce, and its new administrator will have to continue to chart its course through treacherous bureaucratic waters.

NOAA is not a small agency. Its 1987 operating budget was approximately $\$ 1,160$ million, not far behind the National Science Foundation's $\$ 1.620$ million budget. It is the parent agency for the National Weather Service, the National Marine Fisheries Service and the National Ocean Service. It also sponsors satellite data collection activities and supports research programmes on the ocean and atmosphere. But the Reagan administration has not been a strong supporter of NOAA's scientific activities, consistently trying to reduce or eliminate NOAA research programmes.

Commerce secretaries - by organizational charts the overseers of NOAA have tended to be chosen more for their knowledge of trade issues than of NOAA activities. Indeed, in hearings held before his confirmation by the Senate last month, Secretary C. William Verity confessed that before he was asked to head the department he was not sure what NOAA did.

Part of NOAA's financial woes stem from the way its budgets are analysed within the White House. Despite its scientific activities, NOAA's budget is not reviewed at the Office of Management and Budget by the staff that deals with other science agencies. NOAA administrators have a chronic need to educate those who will pay for their programmes.

But NOAA does have its allies. In Congress, Senators Lowell Weicker (Republican. Connecticut) and Ernest Hollings (Democrat, South Carolina) are supporters of the agency. Weicker believes that NOAA should be given the status of an independent agency, like NASA (National Aeronautics and Space Administration) or EPA (Environmental Protection Agency). Although he has introduced legislation that would require that move, the bill is unlikely to go anywhere during this session of Congress. Support for making NOAA independent is not univer- sal: some fear that an independent agency would be more vulnerable to budget cutting, as, unlike NASA, it does not have a strong public identity.

The White House is expected soon to announce its choice for a new administrator to replace Anthony J. Calio who left NOAA last August. Calio resigned as administrator just one week after Malcolm Baldrige's death in the summer. He was widely regarded as having been an effective force for the agency within the administration. Calio says he developed a close working relationship with Baldrige, and was personally shaken by his death in a rodeo accident.

Two names being mentioned as possible successors to Calio are Carl Savit, recently retired from Western Geophysical in Houston, and William E.Evans, currently assistant administrator for fisheries at NOAA Joseph Palca

\section{Czech demand for modern computers \\ London}

Czechoslovakia's import regulations governing personal computers are illconceived and encourage technical backwardness, according to the Czech party daily, Rude Pravo. The present regulations base the duty payable on the memory capacity, which, the paper admits, may seem "simple and reasonable", but which is questionable on two counts.

First, it is not the memory capacity that determines the capabilities of a personal computer, but the speed of operation. Second, the rate of duty is set at 150 Czechoslovak crowns per kilobyte, which becomes prohibitive for the new megabyte memory personal computers.

The demand for personal computers in Czechoslovakia far exceeds the supply. Domestically produced ones are manufactured in very short production runs, the paper notes, and are based on outdated components (for example, the 8080 integrated circuit, or the $\mathrm{Z}-80$ which is only slightly more advanced).

Personal computers and minicomputers are particularly needed, the commentator points out, in the educational sector, from primary schools to universities. Even the specialized primary school for the mathematically gifted has only 14 computers for the entire school. The situation is worst, Rude Pravo notes, in technical universities, "although it is precisely the future engineers who should be working with the latest computer technology while they are studying, rather than being introduced to it later". Vera Rich
US agents claim success over supercomputers

\section{Washington}

US OFFICIAIS say they have plugged a potentially disastrous technology leak by arresting three men accused of trying to sell the Soviet Union plans of a supercomputer being built by Saxpy Computer Corp of Sunnyvale, California. Defence officials say the stolen technology has "a direct military application and would have proven extremely detrimental to US national security if it had gotten to the Soviets"

Sandy Towles, director of market development for Saxpy, said the MATRIX $1 / 1000$ computer, which sells for $\$ 1.9 \mathrm{mil}$ lion, would have been attractive to the Soviet Union because it is constructed primarily from readily available hardware, much of which would not be subject to export control.

The supercomputer is designed for numerically intensive computational environments. It uses SIMD (single instruction, mutiple data) architecture, and can execute as many as 1,000 megaflops (million floating point operations) per second for certain applications. Saxpy has installed one computer at Martin Marietta Corporation in Baltimore, and has sold a second machine to the Canadian company Pulsonic Geophysical Ltd of Calgary, Alberta.

Customs agents began their investigation last August when Ivan-Pierre Batinic, a French national and employee of Saxpy at the time, and Kevin Anderson, a software designer from Fremont, California, attempted to cross the Canadian-United States border at Vancouver with approximately $\$ 10,000$ in $\$ 100$ bills. Anderson and Batinic reportedly received the money from Carlos Julio Williams, a name used on a Guatemalan passport by US citizen Charles McVey. US officials believe McVey was the mastermind behind the technology transfer scheme. $\mathrm{He}$ is currently under arrest in Canada, and US officials are seeking his extradition.

A spokesman for the US Customs service says that in addition to arresting Anderson and Batinic, agents also arrested Batinic's brother Stevan, and recovered computer tapes, floppy disks and documents stolen from Saxpy. The men are expected to be charged with violating US export control laws and attempting to transport stolen materials across state lines. There have been press reports that at least one of the group made contact with Soviet officials, including Dr Roald Sagdeev, but customs officials will not confirm this. 